\title{
Enhancing mastery of students' concept through science technology society (STS) approach on chemical equilibrium
}

\author{
Dwi Rahmi Putri \\ sicence education postgraduate \\ universitas negeri surabaya \\ Surabaya
}

\author{
Leny Yuanita \\ Dept. of Chemistry \\ universitas negeri surabaya \\ Surabaya \\ lenyyuanita@unesa.ac.id
} Bambang Sugiarto
Dept. of Chemistry
universitas negeri surabaya Surabaya 


\begin{abstract}
This study aims to determine the enhancement mastery of students' concepts after being given learning based on the Science Technology Society (STS) approach to Chemical Equilibrium. Students in class XI MIA 1 and XI MIA 2 of Senior High School 4 Sidoarjo be a subject. The design of this study uses an adaptation of the 4-D model by Thiagarajan, et al. The data is obtained from concept mastery tests given before and after learning activities. The data is analyzed qualitative and quantitative descriptive, and inferential statistics. The results of the t-test indicate the value of sig. (2-tailed) $<0.05$ so that there are difference in the mastery of students' concepts before and after being given learning based on the Science Technology Society (STS) approach.
\end{abstract}

Keywords-Science Technology Society Approach, Chemical Equilibrium, Mastery of Students' Concept

\section{INTRODUCTION}

The development of science and technology is progressing so rapidly that a nation is said to be advanced if it can to master both fields. Technology development efforts are appropriate with Law number 202003 concerning the national education system. It can be said that the balance of science and mastery of technology helps students to achieve a higher quality of life. Therefore, education must be able to develop the full potential of students so that they can live in the coming era that has the complexity of the problems that exist today. Especially in chemistry that has a more tangible role for students to live in the community.

Based on the result of the questionnaire filled out by XI MIA 1 and XI MIA 2 at Senior High School 4 Sidoarjo, it was shown that $92.59 \%$ of students felt chemistry was difficult. Also, based on the results of the teacher's interview, it is known that there are still many students who get remedies on material containing counts and memorization, one of them is chemical equilibrium. Chemical equilibrium is one of the chemistry material in class XI. This material requires macroscopic, submicroscopic, symbolic understanding and interrelationships at all levels [12].

One effort to improve students' mastery of concepts is through a planned approach in teaching and learning activities. Effective planning will be able to manage the class well [1]. Based on the results of observations on students, it is known that $77.77 \%$ of teachers still use a teacher-centered approach that is lecturing. This is because the teacher considers the lecture to be a more effective and efficient method based on the available time allocation. One learning approach that can be used to improve students' mastery of concept is the Science Technology Society (STS) approach.

Chemical equilibrium material is considered suitable for the STS approach because it has phenomena that are close to students' daily lives. The phenomena in this material can be approached with technology and knowledge that have been obtained and studied by students. This certainly makes it easier for students to apply in life.

The STS approach in learning contains five domains, namely knowledge, attitudes, scientific processes, creativity and relationships and applications [2]. The STS approach is a learning innovation that utilizes environmental issues in learning activities and theory can form individuals having the ability to foster understanding of concepts as well as creative thinking skills [3].

Research with the STS approach has been carried out by several researchers. Smitha and Aruna [4] found that the STS approach was effective in motivating students to improve learning outcomes. Nuray Yoruk, Inci Morgil and Nilgun Secken [5] reported that learning outcomes between the control class and the experimental class at the time of the posttest. The experimental class (using the STS approach) experienced a significant increase in learning outcomes.

Based on this description, it can be concluded that is need approachment in learning activities, especially in chemical equilibrium to enhance mastery of students' concepts.

\section{MethodHS}

This research method is qualitative and quantitative descriptive and inferential statistics. The research was conducted on 60 students in XI MIA 1 and XI MIA 2 in SMA Negeri 4 Sidoarjo for 4 meetings in May 2019 in the 2018 - 2019 school year.

The first step is taken to analyze the results of mastery of students' concepts test is to calculate the value of mastery of the concept using the following formula:

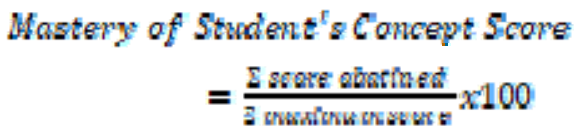

The results are reported in the form of scores and predicates. Achievement of mastery of students' concepts is converted into the titles A to D which are listed in the following Table I.

TABLE I. CONVERT MASTERY OF STUDENT's CONCEPTS SCORES INTO PREDICATES

\begin{tabular}{|c|c|}
\hline $\begin{array}{c}\text { Mastery Of } \\
\text { Student's } \\
\text { Concept Value }\end{array}$ & Predicate \\
\hline$<75$ & D (Less) \\
\hline $75-80$ & C (Enough) \\
\hline $81-86$ & B (Good) \\
\hline $87-100$ & A (Very Good) \\
\hline
\end{tabular}

(Modified from the Ministry of Education and Culture, 2016)

Based on Table I, students are said to be complete when they reach the minimum a value that has been set by the school which is to get a grade with title $\mathrm{C}$.

The second step is to find out the differences in the mastery of students' concepts at the pretest and posttest which are analyzed using the t-test. The requirements for conducting a t-test are that the data must be normally distributed and homogeneity [6]. Normality is seen using the Kolmogorov-Smirnov test on the SPSS application. Data is said to be normally distributed if the results of sig. 
(2-tailed) $>0.05$. Homogeneity is seen by using the SPSS application through the ANOVA test. Data is said to be homogeneous if the result of sig. $>0.05$.

After testing the normality and homogeneity, the t-test is done through the SPSS application. The result of the test is then analyzed, to make a decision whether the proposed hypothesis is accepted or rejected then it is carried out in the following manner.

$\mathrm{Ha}=$ there are differences in the mastery of concepts before and after learning based on the Science Technology Society (STS) approach.

Ho $=$ there is no difference in the mastery of concepts before and after learning based on the Science Technology Society (STS) approach.

If sig (2-tailed) $<0.05, \mathrm{Ha}$ is accepted and Ho is rejected [7].

\section{RESULT OF RESEARCH}

\section{A. Results}

The aim of the approachment of learning to enhance mastery of students' concepts in the Chemical Equilibrium. Sub material which is assessed includes the factors of equilibrium shift, namely 1) change in concentration, 2) change in volume/pressure, 3) change in temperature and 4) influence of catalyst.

The results of research in class XI MIA 1 showed that before the STS approach was applied 27 students got the D title (less), 2 students got the $C$ (enough) and 1 student got the B (good) with a range of score 6.25 - 81.25. After conducting learning activities with the STS approach, the range of scores obtained by students of class XI MIA 1 becomes 62.5 - 97.9. A total of 24 students completed and 6 students incomplete mastering the concept of Chemical Equilibrium.

TABLE II. MASTERY OF CONCEPT VALUE XI MIA 1

\begin{tabular}{lccccc} 
Nu. & Name & \multicolumn{2}{c}{ Pretest } & \multicolumn{2}{c}{ Posttest } \\
& & Score & Predicate & Score & Predicate \\
\hline 1. & AMM & 10,42 & D & 83,3 & B \\
2. & ASR & 8,33 & D & 72,9 & D \\
3. & ATF & 6,25 & D & 89,6 & A \\
4. & ARA & 31,25 & D & 81,3 & B \\
5. & AMA & 77,08 & C & 95,8 & A \\
6. & AMR & 33,33 & D & 95,8 & A \\
7. & ANA & 8,33 & D & 87,5 & A \\
8. & ANO & 14,58 & D & 97,9 & A \\
9. & DRN & 14,58 & D & 68,8 & D \\
10. & DAP & 16,67 & D & 70,8 & D \\
11. & DPS & 16,67 & D & 89,6 & A \\
12. & DRS & 20,83 & D & 85,4 & B \\
13. & EBE & 33,33 & D & 93,8 & A \\
14. & ESR & 75,00 & C & 91,7 & A \\
15. & FAA & 12,5 & D & 93,8 & A \\
16. & FYK & 14,58 & D & 85,4 & B \\
17. & HHI & 31,25 & D & 83,3 & B \\
18. & IYY & 10,42 & D & 72,9 & D \\
19. & MMR & 31,25 & D & 91,7 & A \\
20. & MDR & 33,33 & D & 87,5 & A \\
21. & NRA & 14,58 & D & 85,4 & B \\
22. & PHM & 81,25 & B & 91,7 & A \\
23. & RAI & 35,42 & D & 66,7 & D \\
24. & RAA & 16,67 & D & 91,7 & A \\
25. & RBR & 16,67 & D & 87,5 & A \\
\hline & & & & & \\
\hline
\end{tabular}

\begin{tabular}{cccccc}
\hline Nu. & Name & \multicolumn{2}{c}{ Pretest } & \multicolumn{2}{c}{ Posttest } \\
& & Score & Predicate & Score & Predicate \\
\hline 26. & RKD & 6,25 & D & 89,6 & A \\
27. & RMA & 33,33 & D & 85,4 & B \\
28. & SHY & 10,42 & D & 91,7 & A \\
29. & SNR & 8,33 & D & 89,6 & A \\
30. & SAK & 33,33 & D & 62,5 & D \\
\hline
\end{tabular}

The results of research in class XI MIA 2 showed that as many as 28 students received the D (less) predicate and 2 students received the $\mathrm{C}$ (enough) predicate before the STS approach was applied. The range of scores obtained 6.25 - 77.08. After being given the STS approach, the range of scores obtained by students of class XI MIA 2 becomes 56.3 - 97.9. A total of 22 students completed and 8 students incomplete mastering the concept of Chemical Equilibrium.

TABLE III. MASTERY OF CONCEPT VALUE XI MIA 2

\begin{tabular}{|c|c|c|c|c|c|}
\hline \multirow[t]{2}{*}{ Nu. } & \multirow[t]{2}{*}{ Name } & \multicolumn{2}{|c|}{ Pretest } & \multicolumn{2}{|c|}{ Posttest } \\
\hline & & Score & Predicate & Score & Predicate \\
\hline 1. & AAA & 20,83 & $\mathrm{D}$ & 85,4 & B \\
\hline 2. & ATN & 16,67 & D & 83,3 & B \\
\hline 3. & $\mathrm{ABE}$ & 77,08 & $\mathrm{C}$ & 87,5 & A \\
\hline 4. & AKR & 22,92 & D & 89,6 & A \\
\hline 5. & AAM & 8,33 & $\mathrm{D}$ & 83,3 & B \\
\hline 6. & APF & 16,67 & $\mathrm{D}$ & 95,8 & A \\
\hline 7. & AHR & 25,00 & $\mathrm{D}$ & 97,9 & A \\
\hline 8. & APO & 22,92 & $\mathrm{D}$ & 66,7 & $\mathrm{D}$ \\
\hline 9. & DSP & 14,58 & D & 85,4 & B \\
\hline 10. & DAA & 8,33 & D & 72,9 & D \\
\hline 11. & DIA & 6,25 & $\mathrm{D}$ & 91,7 & A \\
\hline 12. & DHA & 75,00 & $\mathrm{C}$ & 87,5 & A \\
\hline 13. & EZA & 39,58 & $\mathrm{D}$ & 79,2 & $\mathrm{C}$ \\
\hline 14. & EFS & 6,25 & $\mathrm{D}$ & 68,8 & D \\
\hline 15. & FTF & 22,92 & $\mathrm{D}$ & 87,5 & A \\
\hline 16. & GEW & 8,33 & D & 91,7 & A \\
\hline 17. & HAR & 29,17 & $\mathrm{D}$ & 56,3 & D \\
\hline 18. & IRM & 6,25 & $\mathrm{D}$ & 62,5 & $\mathrm{D}$ \\
\hline 19. & IAN & 14,58 & $\mathrm{D}$ & 91,7 & $\mathrm{~A}$ \\
\hline 20. & MRN & 25,00 & $\mathrm{D}$ & 87,5 & $\mathrm{~A}$ \\
\hline 21. & MUP & 16,67 & $\mathrm{D}$ & 64,6 & $\mathrm{D}$ \\
\hline 22. & NBB & 33,33 & $\mathrm{D}$ & 85,4 & B \\
\hline 23. & NVS & 16,67 & D & 83,3 & B \\
\hline 24. & NAN & 18,75 & $\mathrm{D}$ & 62,5 & $\mathrm{D}$ \\
\hline 25. & NPI & 14,58 & $\mathrm{D}$ & 97,9 & A \\
\hline 26. & OPA & 27,08 & D & 91,7 & A \\
\hline 27. & RHM & 41,67 & D & 87,5 & A \\
\hline 28. & RAA & 22,92 & $\mathrm{D}$ & 85,4 & B \\
\hline 29. & SDS & 25,00 & $\mathrm{D}$ & 87,5 & A \\
\hline 30. & SAH & 16,67 & D & 70,8 & D \\
\hline
\end{tabular}

To determine whether there are differences in the average of two sample pairs, a t-test is used. Before the t-test is carried out, the research data must be normally distributed and homogeneity. The results of normality tests and homogeneity tests of class XI MIA 1 and XI MIA 2 indicate that the data are normally distributed and homogeneity, this is because of the results of sig. $>0.05$. After that, the t-test was conducted. Following are the results of t-test on the mastery value of the concepts of class XI MIA 1 and XI MIA 2.

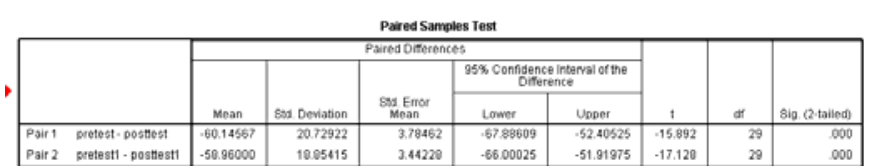


Fig. 1. t-test result

Through the SPSS application, it is known that sig. (2tailed) $<0.05$ which is equal to 0.000 , this shows that there are differences in the mastery of students' concepts before and after learning based on the Science Technology Society (STS) approach.

\section{B. Discussion}

Mastery of students' concept of the Chemical Equilibrium was measured using a mastery of concept test sheet instrument. The test sheet contains 4 questions that refer to the cognitive domain C3 - C6 and represent indicators on the Chemical Equilibrium. Before learning, students are given a pre test to measure the initial ability of students and after the learning process students are given a post test to find out the enhance of mastery of students' concepts after given in learning based on the Science Technology Society (STS) approach.

The concepts obtained by students in these four meetings are the factors of chemical equilibrium shifting including 1) changes in concentration, 2) changes in volume/pressure, 3) changes in temperature and 4) the influence of catalysts. These concepts have been provided in the worksheets which were distributed to each group accompanied by a summary. The concept given is a summary of the material accompanied by examples of reactions and pictures. The provision of this material is intended to facilitate students in understanding the concepts that must be mastered. Also, students are given a phenomenon in the form of issues of science in everyday life and experiments that aim to apply and solidify concepts that students have previously obtained. The Science Technology Society approach can develop cognitive skills, affective skills and psychomotor skills and student creativity [8].

The STS approach requires students to be active both physically and intellectually. For example in the invitation stage, this stage contains issues that occur in the daily lives of students. Where students are required to think critically, act scientifically and be able to relate to the material they have learned [9]. Resolving science issues in life can provide a strong foundation for students to be skilled in making decisions so students become scientifically educated and able to contribute to society [15].

The assessment used refers to the 2013 curriculum, which is a criteria-based assessment. This criteria-based assessment based on minimum completeness criteria that have been determined by the school. Minimum completeness criteria at Senior High School 4 Sidoarjo for chemistry is 75 . The following graphs the results of mastery of students' concepts in class XI MIA 1 and XI MIA 2 during the pre test.

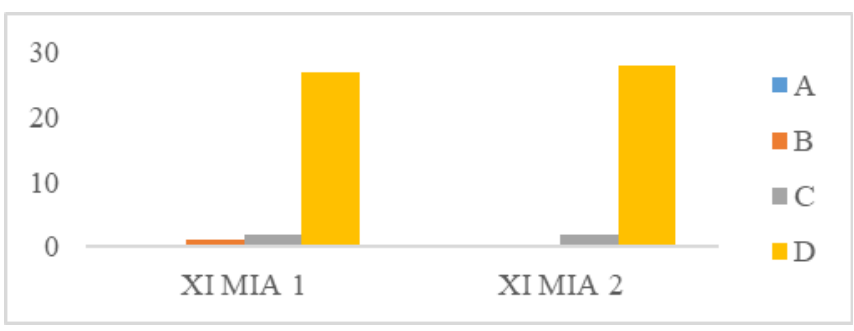

Fig. 2. Graphic Mastery of Concept Results during Pretest

Based on Figure 1 it can be seen that there are many students from class XI MIA 1 and XI MIA 2 who get D grades with less categories. During the pre test, many students were unable to answer the questions given because they did not understand the concept of chemical equilibrium. This is what causes students to not be able to answer questions during the pre test so that the scores obtained are low. Therefore given learning activities with the STM approach to improving students' mastery of concepts. The results of mastering the concepts of students after learning activities can be seen based on the post test scores in the following graph.

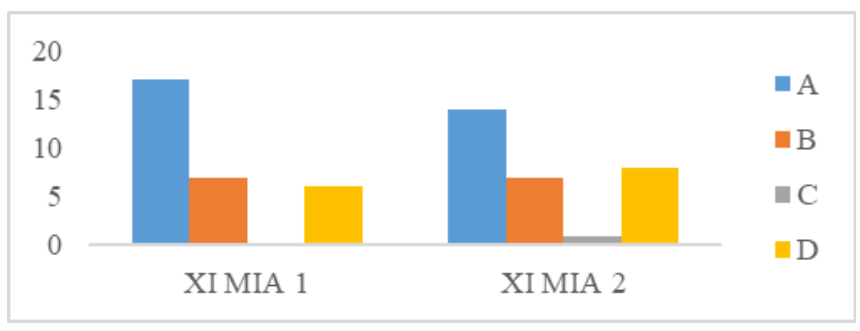

Fig. 3. Graphic Mastery of Concept Results during Posttest

Based on Figure 2 it can be seen that after going through learning based on the Science Technology Society approach, many students in XI MIA 1 and XI MIA 2 class get grades A and B in the good category. These results indicate that learning based on the Science Technology Society (STS) approach is effective in enhancing mastery of the concept of Chemical Equilibrium. The Science Technology Society (STS) approach was able to enhance mastery of students' concept because STS students have been found to actually learn more content than their traditionally taught peers. [14]. The following graph illustrates the percentage of students completed at the pre test and post test in class XI MIA 1 and XI MIA 2.

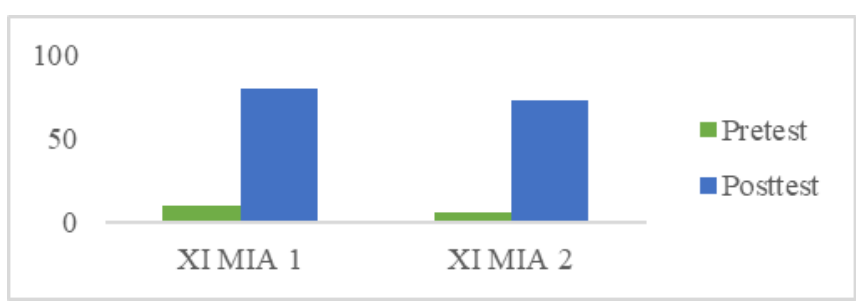

Fig. 4. Graph percentage of completeness of students during pretest and posttest

Based on Figure 3 it can be seen that at the time of the pre test, $10 \%$ of XI MIA 1 and $6.67 \%$ of XI MIA 2 students were declared complete. At the time of the post 
test, $80 \%$ of XI MIA 1 and $73.33 \%$ of XI MIA 2 students were declared complete. As many as $20 \%$ of XI MIA 1 and $27.77 \%$ of XI MIA 2 students who did not complete. This is because the students have not been able to answer well but there is an increase in grades compared to the value at the pre test. In the learning activities seen some students who are less active in groups, discuss and conduct experiments. Because of this, there are still students who find it difficult to answer post test questions to obtain a low grade.

The principle of learning using the STS approach is to discuss issues in society related to science and technology. This approach aims to involve students in problem solving and statements related to problems in their environment and daily life [13]. The STS approach has many benefits that can be obtained by students and teachers, one of which is effective for the mastery of concepts in students [8]. Because the concepts that have been learned are related to actual problems in life so that what is learned is considered useful and the concepts will be easier to construct and have long retention [9].

In line with Piaget, learning is a child's activity when he interacts with his social and physical environment [10]. Also, the use of technology in learning helps students deepen the concepts they get. The theory of constructivism says that students cannot learn to passively absorb or copy the understanding of others, students must build their understanding [11]. By searching for information through sources from the internet that are accurate, reliable and accountable helps students build their understanding by what they get. Besides that the use of technology in learning to build a more lively learning situation so students are actively involved with the subject matter through material processing and social interaction.

Enhanced mastery of students' concepts of the Chemical Equilibrium can be seen based on the results of the t-test on existing data. The t-test is used to determine whether there is an average difference between the two paired samples. Based on the t-test results (Fig.4), it is known that sig $(2$-tailed $)<0.05$. This means that there are differences in the mastery of students' concepts of XI MIA 1 and XI MIA 2 before and after learning

based on the Science Technology Society (STM) approach.

\section{CONCLUSION}

The use of the Science Technology Society approach in learning activities can enhance mastery of students' concepts in the Chemical Equilibrium in XI MIA 1 and XI MIA 2 proven by pre post results and the results of the $t-$ test.

\section{ACKNOWLEDGMENT}

Would like to express an appreciation to Dra. Sri Mudjajanti, M.Pd as headmaster, Nunung Nuryanti, S.Pd as a teacher and student of XI MIA 1 and XI MIA 2 Senior High School 4 Sidoarjo. The highest appreciation is present to two advisors, Prof. Dr. Leny Yuanita, M.Kes, and Dr. Bambang Sugiarto, that have guided research from the beginning until the article finishes.

\section{REFERENCES}

[1] F. Beetleston, Creative Learning Strategi Pembelajaran untuk Melesatkan Kreatifitas Siswa. Bandung: Nusa Media, 2013.

[2] R. Sitiatava Putra, Desain Belajar Mengajar Kreatif Berbasis Sains. Jogjakarta: DIVA Press, 2013.

[3] IGBN Smarabawa, IB. Arnyana and IGAN. Setiawan, "Pengaruh Model Pembelajaran Sains Teknologi Masyarakat terhadap Pemahaman Konsep Biologi dan Keterampilan Berpikir Kreatif Siswa SMA," e-Journal Program Pascasarjana Universitas Pendidikan Ganesha, vol. 3, pp. 1 - 28, 2013.

[4] E.T. Smitha and Dr. P. K. Aruna, "Effect of Science Tecnology Society Approach on Achievement Motivation in Biology of Secondary School Students of Kasaragod District," Journal of Humanities and Social Science, vol. 19, pp. 54 - 58, 2014.

[5] N. Yoruk, Inci Morgil and Nilgun Secken, "The Effects of Science, Technology, Society, Environment (STSE) Interactions on Teaching Chemistry," Journal of Natural Science, vol. 2, pp. 1417 $-1424,2010$

[6] S. Santoso, SPSS 20 Pengolah Data Statistik di Era Informasi. Jakarta: PT Gramedia, 2015.

[7] S. Christianus, Seri Belajar Kilat SPSS 17. Yogyakarta: ANDI, 2010

[8] P. Rizema Sitiatava, Desain Belajar Mengajar Kreatif Berbasis Sains. Jogjakarta: DIVA Press, 2013.

[9] A. Poedjiadi, Sains Teknologi Masyarakat Model Pembelajaran Kontekstual Bermuatan Nilai. Bandung: PT Remaja Rosdakarya, 2010.

[10] T. Gerson Ratumanan, Belajar dan Pembelajaran serta Faktorfaktor yang Mempengaruhinya Edisi Ketiga. Yogyakarta: Pensil Komunika, 2015

[11] D. Gusfrenie, "Model Pembelajaran Teknologi Masyarakat (STM),"Jurnal Edu-Bio, vol. 4, pp. $21-31,2013$.

[12] N. Yildrim, Y. Sengyun, Z. Ceng and A. Ayas, "Evaluating the Effect of Teaching Chemical Equilibrium Based on Analogy and Laboratory on Students Achievement," Procedia Soc Behav Sci, vol. 2, pp. 537-541, 2010.

[13] E. Bakar, S. Bal and H.Akcay, "Preservice Science Teachers Beliefs about Science-Technology and their Implementation in Society," Eurasia Journal of Mathematic, Science and Technlogy Education, vol. 2, pp. $18-32,2006$.

[14] K. Courville, "Science, Technology, and Society: A Perspective on the Enhancement of Scientific Education," Paper Presented at the Louisiana Association of Mathematics Teachers/Louisiana Science Teacher Association Joint Conference, 2009.

[15] F. Abd-El-Khalick, "Socioscientific Issues in Pre-College Classrooms," The Role of Moral Reasoning on Socioscientific Issues and Discourse in Science Education, vol.19, pp. 41 